\title{
Top 100 cited articles on ankylosing spondylitis
}

\author{
F. Bagcier ${ }^{1}$, O.V. Yurdakul' ${ }^{2}$ E. Ozduran ${ }^{3}$ \\ ${ }^{1}$ Department of Physical Medicine and Rehabilitation, Biruni University Faculty of Medicine, Istanbul, Turkey; \\ ${ }^{2}$ Department of Physical Medicine and Rehabilitation, Bezmialem University Faculty of Medicine, Istanbul, Turkey; \\ ${ }^{3}$ Clinic of Physical Medicine and Rehabilitation, Haseki Training and Research Hospital, Istanbul, Turkey
}

\section{SUMMARY}

Ankylosing spondylitis is a global health problem. There are continuous innovations in terms of etiopathogenesis, diagnosis, and treatment. Here, the top 100 most cited articles on ankylosing spondylitis during the last three decades are analyzed.

On April 6, 2020, the Web of Science was screened from 1984 to 2020 using the terms ankylosing spondylitis; the top 100 most cited articles were identified. For bibliometric analysis, the name of the article, year of publication, author information, number of citations, name of the publishing journal, H-index, impact factor, countries of the authors, types of articles, and funding sources were recorded. The Altmetric attention was recorded using a program that automatically calculates the score.

The total number of citations of the articles in the list ranged from 176 to 3700 . Arthritis and Rheumatism $(\mathrm{n}=31)$ and Annals of the Rheumatic Diseases $(\mathrm{n}=27)$ were the two leading journals in which the majority of the articles were published. Germany produced most of the articles; Braun J was the most cited author. Randomized controlled clinical trials were found to constitute most of the articles $(n=35)$. According to the citation number, studies evaluating classification criteria and disease activity indices and, according to the Altmetric Attention Score, studies addressing the prevalence and biological agents were prominent.

We present a perspective on the extent to which the most cited articles on ankylosing spondylitis draw interest in the scientific community and on social media platforms.

Key words: Ankylosing spondylitis; bibliometric analysis: Altmetrics; rheumatic disease.

Reumatismo, 2020; 72 (4): 218-227

\section{INTRODUCTION}

A nkylosing spondylitis (AS) is a chronic inflammatory rheumatic disease of unknown etiology, affecting $0.1 \%$ $1.4 \%$ of the population (1). AS primarily involves sacroiliac joints, followed by the vertebral column and, to a lesser extent, peripheral joints (1). HLA-B27 antigen is highly associated with etiology in patients with AS, where entheseal inflammation is frequently seen (1). Today, imaging methods are widely used in the diagnosis of AS, to evaluate disease activity, degree of structural damage, treatment response, and determination of prognosis (2). With magnetic resonance imaging, changes in soft tissues, cartilage, and bone structures can be detected in the initial period of the disease, providing a significant contribu- tion to early diagnosis, whereas conventional radiographs indicate late manifestations (3). As AS causes disability in the working population, it causes labor loss and brings a substantial economic burden to countries due to the high cost of agents used in its treatment. To date, rapid developments have been seen in clinical trials in the field of AS and the contribution of global data obtained with the participation of many countries is excellent (4).

Although parameters such as the number of citations, impact factor, and H-Index do not directly reflect the quality of an article published in a journal, investigators still rely on citation-based indicators (5). Since these parameters show only the impact of the related articles in the field of science, they cannot evaluate the parameters regarding bureaucracy, country health manage- 
ment, and the public. Recently, social media platforms that are increasingly entering our lives, are having an essential role in promoting medical literature. Altmetrics, the term for alternative metrics, are qualitative data that cover the lack of traditional citations, as they include web citations of the scientific literature and usage-based indicators such as views, downloads, comments, bookmarks, and words from social media (6). It measures interactions captured by social media such as Facebook, Twitter, LinkedIn, and blogs (6). Over the past few years, dissemination and viewing of medical literature by social media have been significantly increased. Thus far, only one study has performed a bibliometric analysis of studies related to AS published between 2008 and 2017 (1). However, no study has evaluated AS-related Altmetric analysis. This study aimed to analyze the top 100 most cited articles in terms of bibliometric and Altmetric analyses.

\section{MATERIALS AND METHODS}

\section{Search strategy}

Web of Science (Clarivate Analytics, Philadelphia, US) is a database of thousands of official journals (http://apps.webofknowledge.com). Along with the general literature search on articles, it has a function of citation index research that allows assessment of the academic importance of an article in a particular field. On April 6, 2020, we conducted an AS search in the Web of Science database from 1984 to 2020 . AS was used as the search term. Related articles were sorted by selecting the times cited option, so articles with higher citation count were ranked at the top. An ethical committee approval was not required because the data used in our study is obtained from published articles.

\section{Study selection}

The abstracts or full texts of the articles were independently screened by two reviewers (FB and OVY) to determine the 100 top articles (T100) on AS with the highest number of citations. When a discrepancy was detected between the two re- viewers, the assessment of a third reviewer (EO) was requested, and a consensus was reached. Only articles focused on the subject of AS were selected.

\section{Data extraction}

For bibliometric analysis, the name of the article, year of publication, number of authors and names of the authors (first author and corresponding author), number of citations, citation index, name of the publishing journal, Q classification, H-index, impact factor, countries of the authors, types of articles, and funding sources were recorded. When the authors were not from the same country, the country of the corresponding author was considered as the country of origin of the paper. Citation index is a parameter calculated every year, obtained by calculating the number of citations independently from the year of publication. Based on the number of years since the article was published, the total number of citations is obtained by proportioning to the number of years (7).

The Altmetric Attention Score was obtained by downloading the Altmetric it function from the Altmetric.com website (https://www.altmetric.com/products/freetools/bookmarklet). The Altmetric Attention Score is calculated automatically using an algorithm based on the weighted number of all the attention a research output receives. The score indicates the weighted number of the amount of attention the Altmetric company has received for a research outcome. The default weight and how the Altmetric Attention Score is calculated can be found on the Altmetric website. The Altmetric Attention Score is based on three main factors: volume, sources, and authors. Each color of the Altmetric donut represents a different social media source of interest. The Altmetric Attention Score and Altmetric donuts are designed to facilitate the demonstration of the quantity and the sources of attention in a particular research outcome (8).

\section{Analysis}

We used IBM SPSS Statistics v21.0 statistical software (Armonk, NY, USA) to per- 
form all statistical analyses. Moreover, we used the Shapiro-Wilk test to test the variable distribution. Descriptive statistics were indicated as mean \pm standard deviation and median, (minimum-maximum), for quantitative variables, whereas frequency and percentage [n (\%)] were indicated for categorical variables. We employed the Spearman's rank correlation analysis to assess the

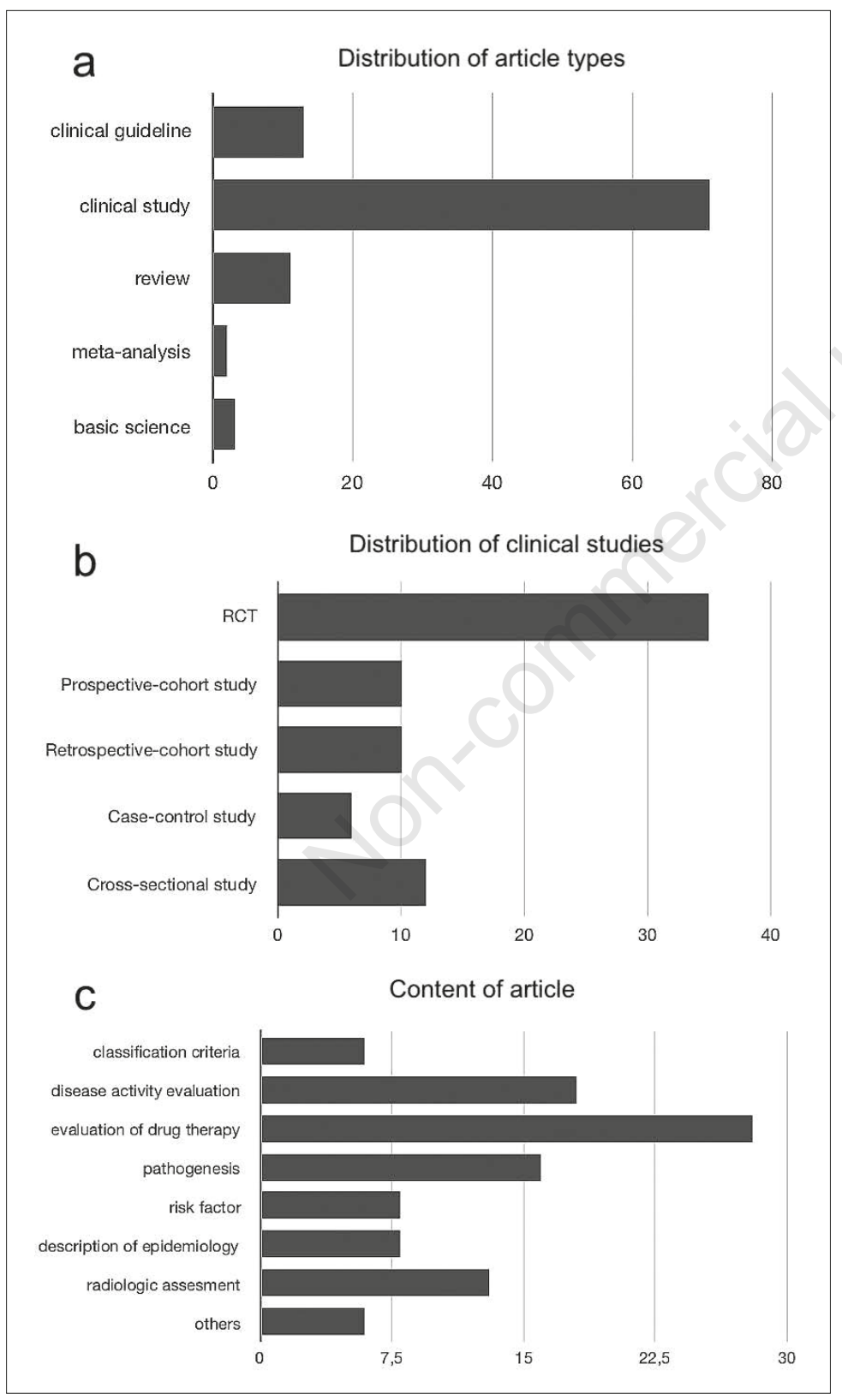

Figure 1 - Characteristics of T100 articles according to: A) distribution of article type; B) distribution of clinical study; and C) content of the article. correlations among non-normal distributing variables. The relations were interpreted as highly correlated when $r$ was $\geq 0.60$, moderately correlated when $r$ was between 0.30 and 0.60 , and weakly correlated when $r$ was $\leq 0.30$ (9). A p-value of $<0.05$ was considered statistically significant for this study.

\section{Ethical consideration}

This article does not contain any studies with human participants or animals performed by any of the authors. Therefore, there is no need for ethical approval.

\section{RESULTS}

On April 6, 2020, screening was performed using the keyword AS for between 1984 and 2020, and a total of 19,874 articles were detected. In Table I, the Top 20 articles of $\mathrm{T} 100$ articles are presented in detail. The total number of citations ranged from 3700 to 176 (\#1 and \#100 in Supplement 1). The mean citation number was $401.43 \pm 459.52$ [median 286 (176-3700)]. The Altmetric Attention Score ranged from 1 to 564 (\#65 and \#77 in Supplement 1), but it was not obtained in 41 articles. The mean Altmetric Attention Score was 14.7 \pm 20.09 [median $3(0-564)]$, and the majority of the articles had an Altmetric Attention Score below 50 $(n=50)$. "Evaluation of Diagnostic-Criteria for Ankylosing-Spondylitis-A Proposal for Modification of the New-York Criteria", by van der Linden et al., 1984, was the most cited article in T100 (\#1). The article with the highest citation index was the article titled "The development of Assessment of SpondyloArthritis international Society classification criteria for axial spondyloarthritis (part II): validation and final selection" published by Rudwaleit et al.

The article titled "Global prevalence of ankylosing spondylitis", published by Dean et al. had the highest Altmetric Attention Score (\#77 in Supplement 1).

According to Table I, the highest number of publications were produced in $2005(n=9)$, followed by $2003(n=8)$ and $2009(n=8)$. In the years after 2016, there were no articles included in the T100. T100 articles were published in 22 journals. Most of the arti- 
cles were published in Arthritis and Rheumatism ( $n=32)$, Annals of the Rheumatic Diseases ( $n=27)$, Journal of Rheumatology $(n=11)$, and Lancet $(n=5)$. The publication language was English in all articles. The majority of articles in T100 $(n=71)$ were clinical trials (Figure 1). Approximately half of them were randomized controlled trials (Figure 1). Germany, the Netherlands, and the USA contributed to most of the articles, whereas Braun J, Sieper J, and Van der Heijde D were the most frequently contributing authors (Figure 2). Braun J participated in nine articles as first author and 12 articles as corresponding author.

The majority of T100 articles originated from European countries (Germany, the Netherlands, and the United Kingdom) and the United States. The participation of Asian and Oceanic countries in the articles was relatively low. T100 articles had a number of authors ranging from 1 to 81 . On the other hand, the vast majority of the articles $(n=77)$ were produced by $\geq 5$ authors.

A moderate correlation was detected between the citation index and the Altmetric score $(\mathrm{p}<0.001, \mathrm{r}=0.577)$. There was also a weak correlation between the total number of citations and the Altmetric score $(\mathrm{p}=0.023, \mathrm{r}=0.228) ; 17$ of the $\mathrm{T} 100$ articles were supported by public organizations, whereas medical companies funded 12 articles and both supported four of them.

\section{DISCUSSION AND CONCLUSIONS}

Altmetric and bibliometric analyses provide important but different information about the value of an article. The studies that evaluate the scientific performance on a specific subject through examining the accumulated scientific data qualitatively and quantitatively on that subject are called bibliometric studies (10). Bibliometric studies ensure close follow-up of the literature and also guide investigators to plan novel studies (11). Altmetrics are a new set of criteria that began to be used in academic and scientific publishing as an alternative to impact factor and other evaluation methods (11). The most favorable feature

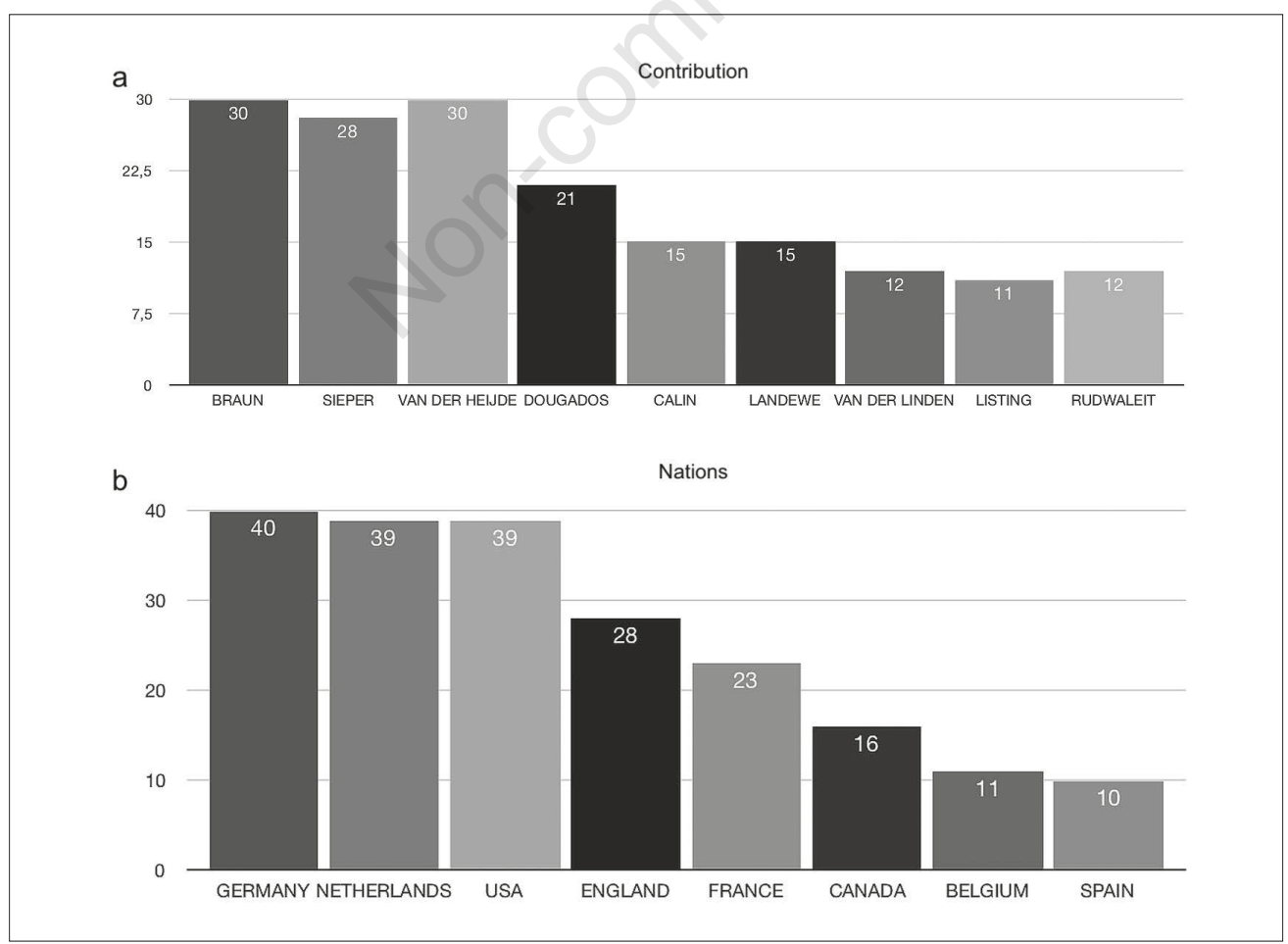

Figure 2 - Number of contributions to T100 articles according to: A) authors and B) countries. 
of it is that it measures not only the number of citations of the article, but also values items such as the number of views and downloads, and impact on social media (8). Designed to monitor further and measure the impact of research online, Altmetrics capture mentions of articles on social media channels such as Twitter, Facebook, Google+ (12). In our study, the T100 articles on AS were examined by Altmetric and bibliometric analysis. We extracted the studies from the Web of Science database and assessed the Altmetric Attention Score for each study, in order to avoid using any non-scientific sources.

In our T100 list, the number of annual articles contributed to the literature reached the highest level after 2004. However, it was seen that the total number of citations increased steadily after 2012, and 2015 was the year with the most cited articles. The vast majority of articles are presented from Germany, the Netherlands, and the United States. The most cited authors were also of European origin. It has been observed that studies evaluating classification criteria and disease activity indices remain at the forefront based on the citation numbers, whereas studies focusing on prevalence and biological agents were prominent given the Altmetric Attention Score.

There is a study in the literature in which AS articles published between 2008 and 2017 were evaluated by the bibliometric method (1). In this article, a period of a rapid increase in the number of AS articles was observed, and this period has been analyzed by the bibliometric method. The publications and citations numbers were evaluated according to the country of origin, and the United States was the leading country in both parameters. China and Turkey were 2nd and 3rd in terms of publication numbers; however, they were not among the leading countries in terms of total citations. This discrepancy brought us to perform an analysis in terms of citations instead of total publication numbers according to the country of origin.

Citation analysis is one of the essential points of bibliometric assessments (7). In our study, only three articles have been cited more than 1500 times (13-15). The vast majority of the articles were cited 500 times or less, and the citation index was between 5.53 and 120.166. In our study, the article published in 1984 on the classification criteria of AS had the highest citation number with 3700 citations (13). The articles in the second and third rank have addressed the assessment of disease activity, with citation numbers of 2098 and 1551, respectively $(14,15)$. However, the article with the highest citation index, and in the fourth rank in total citation number with 1442 citations, is a study in which the classification criteria have been updated (16).

In terms of Altmetric Attention Score, the article with the highest score of 564 is an article that has evaluated AS prevalence globally (17). With 141 and 84 Altmetric Attention Scores, studies evaluating the treatment with infliximab, an agent that we have become more familiar with, and secukinum$\mathrm{ab}$, an agent that has become more popular recently, were in the second and third place $(18,19)$. The Altmetric Attention Score of the article with the highest number of citations was only 7 (13), possibly due to the disadvantage of the lack of social media platforms and blogs in the 1980s.

Articles in the T100 list included subjects on classification criteria in AS, the effectiveness of drug therapy, evaluation of disease activity, etiopathogenesis, risk factors, and radiological assessments. In particular, studies in which medical therapies have been evaluated were found to be at the forefront $(n=26)$. Three of these studies were on nonsteroidal anti-inflammatory drugs and sulfasalazine therapy, whereas all other studies were related to biological drugs (20-22). Regarding these drugs, the short and long-term efficacy and safety, potential side effects, treatment guidelines, effects on extra-articular involvement such as uveitis, and cardiovascular system have been addressed $(23,24)$. Disease activity indices (BASDAI and ASDAS), which are essential for standardizing the follow-up of patients with AS, predicting the disease progression, and evaluating the treatment response, were discussed in 16 articles in the T100 list $(25,26)$. 
The role of genetic and environmental factors in the development of AS remains a mystery. Although $90 \%-95 \%$ of cases with AS are known to be HLA-B27 positive, HLA-B27 constitutes less than 1/3 of the genetic risk factors responsible for the development of AS (27). One study in the T100 list has evaluated the effect of HLAB27 positivity upon the age at onset and diagnosis delay (28). Other than the HLA$\mathrm{B} 27$ of the $\mathrm{MHC}$ region, many genetic factors play a role in the development of AS, and there are also genetic markers outside the $\mathrm{MHC}$ region responsible for the disease (29). Indeed, we see that these issues are covered in depth in the T100 list. Sixteen articles on HLA class-1, Erap-1, non-MHC genes were published in the list (30). Klebsiella pneumoniae, a possible environmental etiological agent responsible for the development of AS, may be involved in the pathogenesis of AS through the molecular mimicry mechanism. This similarity leads to cross-reaction (31). In the T100 list, this topic was also discussed in a study in which the Altmetric Attention Score was 8 (31). It is known that the frequency of AS disease varies geographically (32). In our study, it was seen among T100 articles that the participation of Asian and Oceanian countries had lagged. However, given that the highest Altmetric attention scored article was a prevalence study that evaluates AS globally, it should be considered that AS studies dealing with the issues of global cooperation and participation may attract more attention from society and social media. The study with the second highest Altmetric Attention Score was a study on secukinumab targeting interleukin-17 cytokine, which is thought to play a role in etiopathogenesis of the disease (18). The journal in which this article was published had the highest impact factor among the journals mentioned in our study. Also, the study itself had the sixth-highest citation index compared to other studies. From this point of view, it can be concluded that new developments in the etiopathogenesis and treatment of the disease draw attention from both the academic world and social media platforms.
Today, imaging methods are widely used in the diagnosis, classification, evaluation of disease activity, degree of structural damage, treatment response, and determination of the prognosis of AS $(33,34)$. The relationship between inflammation and subsequent structural damage in AS is complicated, and this course results in imaging findings of inflammation, osteodestruction, osteoproliferation, and associated osteoporosis (34). In the T100 list, 13 articles included radiological imaging methods, and among these methods, magnetic resonance imaging was at the forefront $(35,36)$.

Another focus of studies was the importance of early diagnosis and treatment in AS. Since there is no single standard of tests or criteria for the diagnosis of AS, the main goal is to ensure that the diagnostic criteria identify the disease at an earlier stage. The ASAS criteria, incorporating magnetic resonance imaging findings and the HLA-B27 test, have made the classification much more precise (16). Indeed, it has received interest from both the scientific world and on social media platforms (16). This topic was discussed in six articles on the T100 list.

There was a moderate correlation between the citation index and the Altmetric score $(\mathrm{p}<0.001, \mathrm{r}=0.577)$ and a weak correlation between the total number of citations and the Altmetric score $(\mathrm{p}=0.023, \mathrm{r}=0.228)$. Altmetric analysis has been widely used recently and covers a timespan of $<10$ years (from 2011 to date), and older articles may have lower Altmetric scores. Thus, it may be expected that articles published in the last decade will have higher Altmetric scores. Accordingly, it may be misleading to compare these parameters between articles published in the last decade with older articles.

Limitations of our study are that only the T100 list screened on the Web of Science has been evaluated, and non-English articles were not included. Besides, the selfcitation and the interaction of countries with each other were not evaluated. The potential impact of countries' income levels on the T100 list was also not investigated. Moreover, during the last years, the 
term axial spondyloarthritis has often been used in place of ankylosing spondylitis. In this context, some studies mentioning AS in their content might not be noticed in this study. Since this term is new in the literature, it was necessary to perform the search for ankylosing spondylitis to obtain consistent data throughout the years.

In conclusion, we presented the T100 articles centered on AS with a perspective on the level of interest of the scientific world and social media platforms. Studies where large-scale databases are used, non-English languages are included, and intercountry interactions are recorded, are needed.

\section{Acknowledgements}

The authors would like to thank Enago (www.enago.com) for the English language review.

\section{Conflict of interests}

The authors declare that they have no conflicts of interest.

Table I - General information related to the top 20 articles on ankylosing spondylitis.

\begin{tabular}{|c|c|c|c|c|c|c|c|c|c|c|}
\hline No & Title & $\begin{array}{l}\text { Primary } \\
\text { Author }\end{array}$ & $\begin{array}{c}\text { Corresponding } \\
\text { Author }\end{array}$ & $\begin{array}{l}\text { Source } \\
\text { Title }\end{array}$ & $\begin{array}{c}\text { Publication } \\
\text { Year }\end{array}$ & $\begin{array}{l}\text { Number } \\
\text { of } \\
\text { citations } \\
\text { (Total) }\end{array}$ & $\begin{array}{l}\text { Altmetric } \\
\text { attention } \\
\text { score }\end{array}$ & $\begin{array}{l}\text { Citation } \\
\text { index }\end{array}$ & $\begin{array}{c}\text { Number } \\
\text { of } \\
\text { authors }\end{array}$ & $\begin{array}{l}\text { Article } \\
\text { Type }^{*}\end{array}$ \\
\hline 1 & $\begin{array}{l}\text { Evaluation Of Diagnostic- } \\
\text { Criteria for Ankylosing- } \\
\text { Spondylitıs - A Proposal for } \\
\text { Modification Of the New-York } \\
\text { Criteria }\end{array}$ & $\begin{array}{l}\text { Vander } \\
\text { Linden } \\
\text { et al. }\end{array}$ & Vander Linden & $\begin{array}{l}\text { Arthritis and } \\
\text { Rheumatism }\end{array}$ & 1984 & 3700 & 7 & 100 & 3 & 1 \\
\hline 2 & $\begin{array}{l}\text { A New Approach To } \\
\text { Definıng Disease Status In } \\
\text { Ankylosing-Spondylitıs - the } \\
\text { Bath Ankylosing-Spondylitıs } \\
\text { Disease-Activity Index }\end{array}$ & $\begin{array}{l}\text { Garrett } \\
\text { et al. }\end{array}$ & Garrett & $\begin{array}{c}\text { Journal of } \\
\text { Rheumatology }\end{array}$ & 1994 & 2098 & 3 & 77,7 & 6 & 1 \\
\hline 3 & $\begin{array}{l}\text { A New Approach To } \\
\text { Defining Functional Ability In } \\
\text { Ankylosing-Spondylitıs - the } \\
\text { Development of the Bath } \\
\text { Ankylosing-Spondylitis } \\
\text { Functional Index }\end{array}$ & Calin et al. & Palin & $\begin{array}{c}\text { Journal of } \\
\text { Rheumatology }\end{array}$ & 1994 & 1551 & 0 & 57,44 & 7 & 1 \\
\hline 4 & $\begin{array}{l}\text { The Development } \\
\text { of Assessment Of } \\
\text { Spondyloarthritis } \\
\text { international Society } \\
\text { Classification Criteria for } \\
\text { Axial Spondyloarthritis (Part } \\
\text { II): Validation and Final } \\
\text { Selection }\end{array}$ & $\begin{array}{l}\text { Rudwaleit } \\
\text { et al. }\end{array}$ & Rudwaleit & $\begin{array}{l}\text { Annals of the } \\
\text { Rheumatic } \\
\text { Diseases }\end{array}$ & 2009 & 1442 & 33 & 120,16 & 23 & 1 \\
\hline 5 & Ankylosing Spondylitis & Braun et al. & Braun & Lancet & 2007 & 1048 & 9 & 74,86 & 2 & 3 \\
\hline 6 & $\begin{array}{l}\text { Treatment of Active } \\
\text { Ankylosing Spondylitis with } \\
\text { infliximab: A Randomised } \\
\text { Controlled Multicentre Trial }\end{array}$ & $\begin{array}{l}\text { Braun } \\
\text { et al. }\end{array}$ & Braun & Lancet & 2002 & 969 & 9 & 51 & 14 & 2 \\
\hline 7 & $\begin{array}{l}\text { Defining Spınal Mobility In } \\
\text { Ankylosing-Spondylitıs (As) - } \\
\text { the Bath As Metrology Index }\end{array}$ & $\begin{array}{l}\text { Jenkınson } \\
\text { et al. }\end{array}$ & Jenkınson & $\begin{array}{c}\text { Journal of } \\
\text { Rheumatology }\end{array}$ & 1994 & 737 & 0 & 27,3 & 6 & 1 \\
\hline 8 & $\begin{array}{l}\text { The Assessment of } \\
\text { Spondyloarthritis } \\
\text { International Society } \\
\text { Classification Criteria for } \\
\text { Peripheral Spondyloarthritis } \\
\text { and for Spondyloarthritis in } \\
\text { General. }\end{array}$ & $\begin{array}{l}\text { Rudwaleit } \\
\text { et al. }\end{array}$ & Rudwaleit & $\begin{array}{c}\text { Annals of the } \\
\text { Rheumatic } \\
\text { Diseases }\end{array}$ & 2011 & 644 & 17 & 64,4 & 19 & 1 \\
\hline
\end{tabular}




\begin{tabular}{|c|c|c|c|c|c|c|c|c|c|c|}
\hline No & Title & $\begin{array}{l}\text { Primary } \\
\text { Author }\end{array}$ & $\begin{array}{c}\text { Corresponding } \\
\text { Author }\end{array}$ & $\begin{array}{l}\text { Source } \\
\text { Title }\end{array}$ & $\begin{array}{c}\text { Publication } \\
\text { Year }\end{array}$ & $\begin{array}{l}\text { Number } \\
\text { of } \\
\text { citations } \\
\text { (Total) }\end{array}$ & $\begin{array}{l}\text { Altmetric } \\
\text { attention } \\
\text { score }\end{array}$ & $\begin{array}{l}\text { Citation } \\
\text { index }\end{array}$ & $\begin{array}{c}\text { Number } \\
\text { of } \\
\text { authors }\end{array}$ & $\begin{array}{l}\text { Article } \\
\text { Type }^{*}\end{array}$ \\
\hline 9 & $\begin{array}{l}2010 \text { Update of the Asas/ } \\
\text { Eular Recommendations } \\
\text { for the Management Of } \\
\text { Ankylosing Spondylitis }\end{array}$ & $\begin{array}{l}\text { Gorman } \\
\text { et al. }\end{array}$ & Gorman & $\begin{array}{l}\text { New England } \\
\text { Journal of } \\
\text { Medicine }\end{array}$ & 2011 & 634 & 34 & 63,4 & 28 & 3 \\
\hline 10 & $\begin{array}{l}\text { Treatment of Ankylosing } \\
\text { Spondylitis By inhibition Of } \\
\text { Tumor Necrosis Factor Alpha }\end{array}$ & $\begin{array}{l}\text { Gorman } \\
\text { et al. }\end{array}$ & Goldenberg & $\begin{array}{l}\text { Jama-Journal } \\
\text { of the } \\
\text { American } \\
\text { Medical } \\
\text { Association }\end{array}$ & 2002 & 598 & 0 & $31-47$ & 3 & 2 \\
\hline 11 & $\begin{array}{l}\text { Efficacy and Safety of } \\
\text { infliximab in Patients with } \\
\text { Ankylosing Spondylitis - } \\
\text { Results of A Randomized, } \\
\text { Placebo-Controlled Trial } \\
\text { (ASSERT) }\end{array}$ & $\begin{array}{l}\text { van der } \\
\text { Heijde } \\
\text { et al. }\end{array}$ & van der Heijde & $\begin{array}{l}\text { Arthritis and } \\
\text { Rheumatism }\end{array}$ & 2005 & 578 & & 36,13 & 11 & 2 \\
\hline 12 & $\begin{array}{l}\text { Recombinant Human Tumor } \\
\text { Necrosis Factor Receptor, } \\
\text { (Etanercept) for Treating } \\
\text { Ankylosing Spondylitis - A } \\
\text { Randomized, Controlled Trial }\end{array}$ & Davis et al. & Davis & $\begin{array}{l}\text { Arthritis and } \\
\text { Rheumatism }\end{array}$ & 2003 & 569 & 9 & 31,61 & 10 & 2 \\
\hline 13 & $\begin{array}{l}\text { Efficacy and Safety of } \\
\text { Adalimumab in Patients } \\
\text { with Ankylosing Spondylitis } \\
\text { - Results of A Multicenter, } \\
\text { Randomized, Double-Blind, } \\
\text { Placebo-Controlled Trial }\end{array}$ & $\begin{array}{l}\text { van der } \\
\text { Heijde }\end{array}$ & Davis & $\begin{array}{l}\text { Arthritis and } \\
\text { Rheumatism }\end{array}$ & 2006 & 558 & 10 & 37,2 & 11 & 2 \\
\hline 14 & $\begin{array}{l}\text { Use of Immunohistologic } \\
\text { and In-Situ Hybridızation } \\
\text { Techniques In the } \\
\text { Examınation Of Sacroiliac } \\
\text { Joint Biopsy Specımens } \\
\text { From Patients with } \\
\text { Ankylosing-Spondylitıs }\end{array}$ & $\begin{array}{l}\text { Braun } \\
\text { et al. }\end{array}$ & Braun & $\begin{array}{l}\text { Arthritis and } \\
\text { Rheumatism }\end{array}$ & 1995 & 548 & 0 & 21,08 & 9 & 2 \\
\hline 15 & $\begin{array}{l}\text { Interaction Between ERAP1 } \\
\text { and HLA-B27 in Ankylosing } \\
\text { Spondylitis Implicates } \\
\text { Peptide Handling in the } \\
\text { Mechanism for HLA-B27 in } \\
\text { Disease Susceptibility }\end{array}$ & $\begin{array}{l}\text { Evans } \\
\text { et al. }\end{array}$ & Evans & $\begin{array}{l}\text { Nature } \\
\text { Genetics }\end{array}$ & 2011 & 501 & 10 & 50,1 & 81 & 2 \\
\hline 16 & $\begin{array}{l}\text { Age at Disease Onset and } \\
\text { Diagnosis Delay in HLA-B27 } \\
\text { Negative vs Positive Patients } \\
\text { with Ankylosing Spondylitis }\end{array}$ & $\begin{array}{c}\text { Feldtkeller } \\
\text { et al. }\end{array}$ & Feldtkeller & $\begin{array}{l}\text { Rheumatology } \\
\text { International }\end{array}$ & 2003 & 498 & 6 & 27,67 & 5 & 2 \\
\hline 17 & $\begin{array}{l}\text { ASAS/EULAR } \\
\text { Recommendations for the } \\
\text { Management of Ankylosing } \\
\text { Spondylitis }\end{array}$ & $\begin{array}{l}\text { Zochling } \\
\text { et al. }\end{array}$ & Braun & $\begin{array}{l}\text { Annals of the } \\
\text { Rheumatic } \\
\text { Diseases }\end{array}$ & 2006 & 497 & 3 & 33,13 & 22 & 1 \\
\hline 18 & $\begin{array}{l}\text { Cardiovascular Disease and } \\
\text { Risk Factors in Patients } \\
\text { with Rheumatoid Arthritis, } \\
\text { Psoriatic Arthritis, and } \\
\text { Ankylosing Spondylitis }\end{array}$ & Han et al. & Han & $\begin{array}{c}\text { Journal of } \\
\text { Rheumatology }\end{array}$ & 2006 & 480 & 1 & 32 & 6 & 2 \\
\hline
\end{tabular}




\begin{tabular}{|c|c|c|c|c|c|c|c|c|c|c|}
\hline No & Title & $\begin{array}{l}\text { Primary } \\
\text { Author }\end{array}$ & $\begin{array}{l}\text { Corresponding } \\
\text { Author }\end{array}$ & $\begin{array}{l}\text { Source } \\
\text { Title }\end{array}$ & $\begin{array}{c}\text { Publication } \\
\text { Year }\end{array}$ & $\begin{array}{l}\text { Number } \\
\text { of } \\
\text { citations } \\
\text { (Total) } \\
\end{array}$ & $\begin{array}{c}\text { Altmetric } \\
\text { attention } \\
\text { score }\end{array}$ & $\begin{array}{l}\text { Citation } \\
\text { index }\end{array}$ & $\begin{array}{c}\text { Number } \\
\text { of } \\
\text { authors }\end{array}$ & $\begin{array}{l}\text { Article } \\
\text { Type* }^{*}\end{array}$ \\
\hline 19 & $\begin{array}{l}\text { Ankylosing Spondylitis } \\
\text { Assessment Group } \\
\text { Preliminary Definition of } \\
\text { Short-Term Emprovement in } \\
\text { Ankylosing Spondylitis }\end{array}$ & $\begin{array}{l}\text { Anderson } \\
\text { et al. }\end{array}$ & Anderson & $\begin{array}{l}\text { Arthritis and } \\
\text { Rheumatism }\end{array}$ & 2001 & 470 & 0 & 23,5 & 5 & 2 \\
\hline 20 & \begin{tabular}{|l|} 
Nonsteroidal \\
Antinflammatory Drugs \\
Reduce Radiographic \\
Progression in Patients with \\
Ankylosing Spondylitis - A \\
Randomized Clinical Trial
\end{tabular} & $\begin{array}{l}\text { Wanders } \\
\text { et al. }\end{array}$ & Wanders & $\begin{array}{l}\text { Arthritis and } \\
\text { Rheumatism }\end{array}$ & 2005 & 459 & 20 & 28,69 & 8 & 2 \\
\hline
\end{tabular}

\section{REFERENCES}

1. Zhao X, Chen J, Pan Y, et al. A bibliometric analysis of the global research in ankylosing spondyloarthritis (2008-2017). Rheumatol Int. 2019; 39: 1091-7.

2. Ostergaard M, Lambert RG. Imaging in ankylosing spondylitis. Ther Adv Musculoskelet Dis. 2012; 4: 301-11.

3. Hermann KG, Althoff CE, Schneider U, et al. Spinal changes in patients with spondyloarthritis: comparison of MR imaging and radiographic appearances. Radiographics. 2005; 25: 559-69.

4. Borchert K, Meise D, König C, Braun S. Ankylosing spondylitis causes high burden to patients and the healthcare system: results from a German claims database analysis. Rheumatol Int. 2018; 38: 2121-31.

5. Bornmann L, Marx W, Gasparyan AY, Kitas GD. Diversity, value and limitations of the journal impact factor and alternative metrics. Rheumatol Int. 2012; 32: 1861-7.

6. Zimba O, Radchenko O, Strilchuk L. Social media for research, education and practice in rheumatology. Rheumatol Int. 2020; 40: 183-90.

7. Yin X, Cheng F, Wang X, et al. Top 100 cited articles on rheumatoid arthritis: a bibliometric analysis. Medicine. 2019; 98: 8.

8. Celik E, Dokur M, Uysal BB, et al. Comparison of attention for cancer research on social media versus academia: An altmetric score analysis. Int J Hematol Oncol. 2020; 30: 032042.

9. Andresen EM. Criteria for assessing the tools of disability outcomes research. Arch Phys Med Rehabil. 2000; 81: S15-20.

10. Mansoori P. 50 years of Iranian clinical, biomedical, and public health research: a bibliometric analysis of the Web of Science Core Collection (1965-2014). J Glob Health. 2018; 10.7189/jogh.08.020701.

11. Trueger NS, Thoma B, Hsu CH, et al. The alt- metric score: a new measure for article-level dissemination and impact. Ann Emerg Med. 2015, 66: 549-53.

12. Huang W, Wang P, Wu Q. A correlation comparison between Altmetric Attention Scores and citations for six PLOS journals. PLoS One. 2018; 13: 4.

13. Linden SVD, Valkenburg HA, Cats A. Evaluation of diagnostic criteria for ankylosing spondylitis. Arthritis Rheum. 1984; 27: 361-8.

14. Garrett S, Jenkinson T, Kennedy LG, et al. A new approach to defining disease status in ankylosing spondylitis: the Bath Ankylosing Spondylitis Disease Activity Index. J Rheumatol. 1994; 21: 2286-91.

15. Calin A, Garrett S, Whitelock H, et al. A new approach to defining functional ability in ankylosing spondylitis: the development of the Bath Ankylosing Spondylitis Functional Index. J Rheumatol. 1994; 21: 2281-5.

16. Rudwaleit M, Van Der Heijde D, Landewé $\mathrm{R}$, et al. The development of Assessment of SpondyloArthritis international Society classification criteria for axial spondyloarthritis (part II): validation and final selection. Ann Rheum Dis. 2009; 68: 777-83.

17. Dean LE, Jones GT, MacDonald AG, et al. Global prevalence of ankylosing spondylitis. Rheumatology. 2014; 53: 650-7.

18. Baeten D, Sieper J, Braun J, et al. Secukinum$\mathrm{ab}$, an interleukin-17A inhibitor, ankylosing spondylitis. N Engl J Med. 2015; 373: 2534-48.

19. Park W, Hrycaj P, Jeka S, et al. A randomised, double-blind, multicentre, parallel-group, prospective study comparing the pharmacokinetics, safety, and efficacy of CT-P13 and innovator infliximab in patients with ankylosing spondylitis: the PLANETAS study. Ann Rheum Dis. 2013; 72: 1605-12.

20. Dougados M, Béhier JM, Jolchine I, et al. Efficacy of celecoxib, a cyclooxygenase 2 - specific inhibitor, in the treatment of ankylosing spondylitis: a six week controlled study with 
comparison against placebo and against a conventional nonsteroidal antiinflammatory drug. Arthritis Rheum. 2001; 44: 180-5.

21. Wanders A, Heijde DVD, Landewé R, et al. Nonsteroidal antiinflammatory drugs reduce radiographic progression in patients with ankylosing spondylitis: a randomized The trial. Arthritis Rheum. 2005; 52: 21054.

22. Clegg DO, Reda DJ, Weisman $\mathrm{MH}$, et al. Comparison of sulfasalazine and placebo in the treatment of ankylosing spondylitis. A Department of Veterans Affairs Cooperative Study. Arthritis Rheum. 1996; 39: 2004-12.

23. Braun J, Baraliakos X, Listing J, Sieper J. Decreased incidence of anterior uveitis in patients with ankylosing spondylitis treated with the anti-tumor necrosis factor agents infliximab and etanercept. Arthritis Rheum. 2005; 52: 21197.

24. Burmester GR, Panaccione R, Gordon KB, et al. Adalimumab: term safety in 23458 patients from global patient trials in rheumatoid arthritis, juvenile idiopathic arthritis, ankylosing spondylitis, psoriatic arthritis, psoriasis and Crohn's disease. Ann Rheum Dis. 2013; 72: 517-24.

25. Lukas C, Landewé R, Sieper J, et al. Assesswment of SpondyloArthritis international Society. Development of an ASAS-endorsed disease activity score (ASDAS) in patients with ankylosing spondylitis. Ann Rheum Dis. 2009; 68: 18-24.

26. Rudwaleit M, Listing J, Brandt J, et al. Prediction of a major clinic response (BASDAI 50) to tumour necrosis factor $\alpha$ blockers in ankylosing spondylitis. Ann Rheum Dis. 2004; 63: 665-70.

27. Bennett AN, McGonagle D, O'Connor P, et al. Severity of baseline magnetic resonance imaging - evident sacroiliitis and HLA - B27 status in early inflammatory back pain predict radiographically evident ankylosing spondylitis at eight years. Arthritis Rheum. 2008; 58: 3413-8.
28. Feldtkeller E, Khan MA, van der Heijde D, et al. Age at disease onset and diagnosis delay in HLA-B27 negative vs. positive patients with ankylosing spondylitis. Rheumatol Int. 2003; 23: 61-6.

29. Reveille JD, Sims AM, Danoy P, et al. Genome-wide association study of ankylosing spondylitis identifies non-MHC susceptibility loci. Nat Genet. 2010; 42: 123.

30. Laval SH, Timms A, Edwards S, et al. Wholegenome screening in ankylosing spondylitis: evidence of non-MHC genetic-susceptibility loci. Am J Hum Genet. 2001; 68: 918-26.

31. Reveille JD, Ball EJ, Khan MA. HLA-B27 and genetic predisposing factors in spondyloarthropathies. Curr Opin Rheumatol. 2001; 13; 265-72.

32. Chou CT, Pei L, Chang DM, et al. Prevalence of rheumatic diseases in Taiwan: a population study of urban, suburban, rural differences. J Rheumatol. 1994; 21: 3026.

33. Braun J, Baraliakos X, Golder W, et al. Magnetic resonance imaging examinations of the spine in patients with ankylosing spondylitis, before and after successful therapy with infliximab: evaluation of a new scoring system. Arthritis Rheum. 2003; 48: 1126-36.

34. Yurdakul OV, Rezvani A. Can ultrasound be an assessment tool for sagittal spine mobility and chest expansion in patients with ankylosing spondylitis?. Medicine 2018; 97: 39.

35. Maksymowych WP, Chiowchanwisawakit $\mathrm{P}$, Clare T, et al. Inflammatory lesions of the spine on magnetic resonance imaging predict the development of new syndesmophytes in ankylosing spondylitis: evidence of a relationship between inflammation and new bone formation. Arthritis Rheum. 2009; 60: 93-102.

36. Bennett AN, McGonagle D, O'Connor P, et al. Severity of baseline magnetic resonance imaging - evident sacroiliitis and HLA - B27 status in early inflammatory back pain predict radiographically evident ankylosing spondylitis at eight years. Arthritis Rheum. 2008; 58: 3413-8. 